POLAR RESEARCH

\title{
Russians celebrate Vostok victory
}

\section{Team finally drills into biggest Antarctic subglacial lake.}

\section{BY NICOLA JONES}

$\mathrm{A}$ fter two decades of chilly drilling and fiery debate, a Russian team has finally broken into Lake Vostok. The largest of the lakes hidden under Antarctica's ice, and the most deeply buried, Vostok has been isolated for millions of years and may contain specially adapted microorganisms. "I'm sure they're drinking vodka this week," says John Priscu, an Antarctic researcher at Montana State University in Bozeman, who has been in contact with the Russian team.

According to Valery Lukin, director of the Russian Antarctic programme, the drill hit lake water 3,769.3 metres down at 10:25 p.m. on 5 February local time (see 'Long way down'). Temperatures were plummeting as the Antarctic summer ended, and scientists left the next day before it became too cold for planes to fly safely. "Talk about suspense. It has been a nailbiter for the past couple of weeks," says Priscu.

Although the Russian scientists have taken samples, which are most likely to be from a pocket of water just above the lake (one container was presented to Russian Prime Minister Vladimir Putin with great fanfare), they will have to wait until December to extract any frozen lake samples, and until 2013-14 to retrieve unfrozen lake water. "This is a technological achievement. The scientific pay-off is still many years away," says Mahlon Kennicutt, president of the international Scientific Committee on Antarctic Research.

The Vostok drilling project began as an ice-coring effort to examine ancient climatic conditions. By the mid-1990s, scientists had confirmed that a giant lake lurked beneath the borehole and speculated that sampling its water might yield signs of ancient life ${ }^{1}$. By the end of the 1990s, the research community had agreed that the Vostok drilling should stop until researchers could be sure that the lake would be protected from contamination by the unsterile kerosene and Freon being used as drilling fluids. Drilling started up again in 2005 with a new plan: when the drill neared the lake, it would be replaced with a thermal probe to melt through the ice, and a plug of clean silicone fluid that would help to protect the lake water from the dirty kerosene above ${ }^{2}$.

Although it is unclear whether the Russian team used the thermal probe and silicone, it probably avoided contaminating the lake. When the drill broke through to the lake, water surged roughly 30-40 metres up the borehole, forcing 1.5 cubic metres of drilling fluid out of the top of the hole. "If everything went as they said, the only flow would be out of the lake, not into the lake," says Kennicutt.

The lake water at the bottom of the hole will freeze, and the researchers plan to drill it out next season. Previous studies found cells in samples of accretion ice ${ }^{3}$ - the bottom couple of hundred metres of the glacier made from frozen lake water - but contamination has not been ruled out. The fresh ice plug is unlikely to clear up that controversy, because the samples must be brought to the surface through drilling kerosene, says Kennicutt. The freezing process may also exclude or kill microbes, he adds.

The Russian team plans to explore the lake in 2013-14 using a variety of probes, cameras and water samplers carried down the borehole in a hermetically sealed container. One probe will measure physical conditions such as temperature and acidity, while another will carry a spectrometer to study any organic compounds in the water.

Meanwhile, the United Kingdom and the United States aim to sample water and sediments from different Antarctic subglacial lakes a year earlier, in 2012-13. Both projects will use heated glacier meltwater to bore holes that should stay open for 24 hours, a cleaner and quicker process that should allow the UK team to get through 3.1 kilometres of ice into Lake Ellsworth in just 3 days. Vostok's thicker glacier and lower temperatures would have made the process too energy-intensive to be practical there, however.

Kennicutt hopes that the Vostok, Ellsworth and US Lake Whillans projects will form the first three nodes of a network that will better sample the hundreds of subglacial Antarctic lakes. "They're not actually at the extremes of pressure and temperature, but they are limited in nutrients and energy," says Kennicutt. If life is eventually confirmed to reside in these inhospitable places, "the question is how microbes make a living down there".

\footnotetext{
1. Kapitsa, A. P., Ridley, J. K., Robin, G. de O.. Siegert, M. J. \& Zotikov, I. A. Nature 381, 684-686 (1996)

2. Lukin, V. \& Bulat, S. Geophys. Monogr. Ser. 192 187-197 (2011)
}

3. Karl, D. M. et al. Science 286, 2144-2147 (1999).
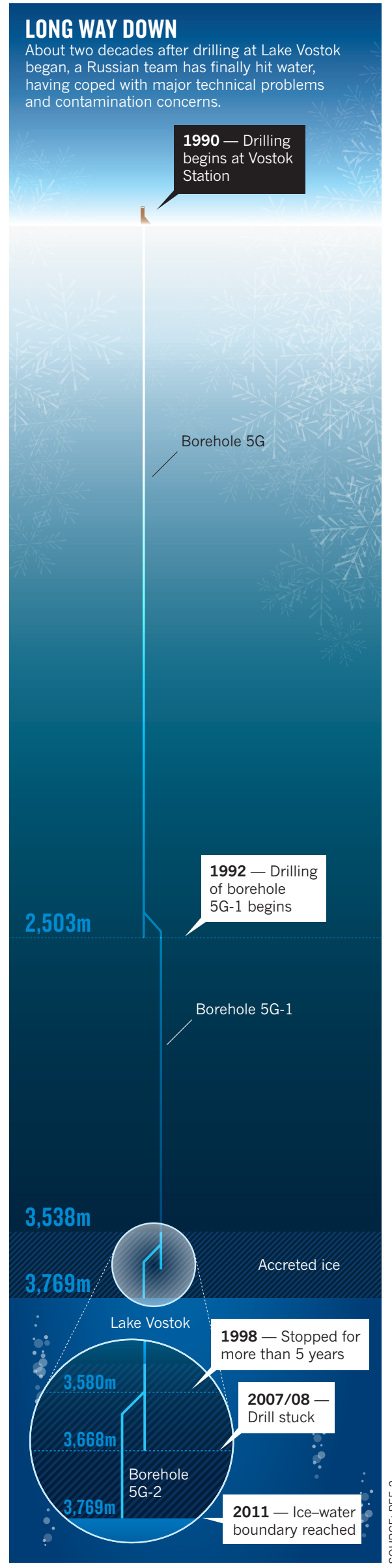